\title{
Attitudes and Practices of Senegalese Dentists towards Hepatitis B
}

\section{Massamba Diouf', Jean-Claude Guinan², Amadou Dieng33, Mbatio Diop1, Aida Kanouté1, Abou Dramane Sanghare2, Ndeye Amina Diop33, Daouda Cisse1, Cheikh Mamadou Mbacke Lo1, Daouda Faye ${ }^{1}$}

\author{
${ }^{1}$ Public Health Service, Department of Dentistry, Cheikh Anta Diop University, Dakar, Senegal \\ ${ }^{2}$ Public Health Service, Faculty of Dentistry, Felix H Boigny University, Abidjan, Côte d'Ivoire \\ ${ }^{3}$ Service of Dentistry, Health Office, Dakar, Senegal \\ Email: dioufmass78@yahoo.fr
}

How to cite this paper: Diouf, M., Guinan, J.-C., Dieng, A., Diop, M., Kanouté, A., Sanghare, A.D., Diop, N.A., Cisse, D., Lo, C.M.M. and Faye, D. (2017) Attitudes and Practices of Senegalese Dentists towards Hepatitis B. Open Journal of Epidemiology, 7, 317-325.

https://doi.org/10.4236/ojepi.2017.74026

Received: September 4, 2017

Accepted: October 16, 2017

Published: October 19, 2017

Copyright () 2017 by authors and Scientific Research Publishing Inc. This work is licensed under the Creative Commons Attribution International License (CC BY 4.0).

http://creativecommons.org/licenses/by/4.0/

\begin{abstract}
Introduction: Hepatitis B is an infectious viral disease that causes inflammation of the liver. It is transmitted through body secretions and fluids, including genital secretions, saliva and blood. The objective of this study was to assess the attitudes and practices of dental surgeons in the face infection of $\mathrm{He}$ patitis B. Methods: This was a descriptive, cross-sectional a sample of 171 dental surgeons. Probabilistic multi-stage, stratified, and systematic sampling was used. Using a questionnaire, we gathered variables related to the attitudes and practices of dentists with respect to Hep B. Results: Nearly $22 \%$ of dentists were not vaccinated against hepatitis B virus; Compliance with the use of gloves, glasses, professional clothing, and hygiene in dental offices was not systematic. Blood exposure accidents (BEA) were common, with nearly $13 \%$ suffering from needle stick injuries, $10 \%$ from eye splashes and about $6 \%$ from sharp instruments. The majority of the actions to be taken in the event of (BEA) were disinfection in the event of sticks or injuries (52.1\%) and rinsing in the event of eye splashes (66.7\%). Conclusion: Dentists should be educated and informed about the need for vaccination and hygiene, sterilization, and good behaviour in case of exposure to blood.
\end{abstract}

\section{Keywords}

Attitudes, Practices, Hepatitis B, Dentist, Senegal

\section{Introduction}

Hepatitis B is an infectious disease caused by hepatitis B virus (HBV) and causes 
inflammation of the liver. It is transmitted by secretions and bodily fluids, including genital secretions, saliva and blood.

It is an affection that is a major public health problem and is the most serious form of viral hepatitis.

In 2014, over 240 million suffer from chronic (long-lasting) hepatic infection worldwide. More than 780,000 people die each year from acute or chronic hepatitis B effects [1].

The prevalence is very variable in different parts of the world. In East Asia, the Middle East and parts of South America, 8\% - 15\% of the population have detectable antigens (HBsAg). The prevalence of chronic portage HBsAg is $2 \%-7 \%$ in Japan, South America, Eastern and southern Europe, parts of Central Asia and Alaska natives. In other countries, the percentage of chronically infected patients with HBV is less than 2\% [2] [3].

In black Africa, prevalence often exceeds $15 \%$. In Senegal, it is estimated that $85 \%$ of the population have at least one marker of the hepatitis B virus. After an acute infection, $20 \%$ become chronic carriers. $17 \%$ of the Senegalese population are chronic carriers [4]. Hepatitis B-related mortality has not been evaluated in Senegal, but it appears to be high.

Despite the magnitude of the problem and hepatitis B policies and programs, medical personnel and especially dentists are considered a high-risk group for HBV infection. The frequency of accidental exposure to blood, the ignorance of, or neglect to take appropriate measures after BEA, failure to comply with international standards of sterilization, disinfection or decontamination, as well as lack of information on the medical status of patients, are all factors risk exposure of both patient and dental surgeon to expose hepatitis B infection. Iserson et al. [5] found a global prevalence of HBV serological markers of $16 \%$ in general dentists. These markers were present in $8.7 \%$ of dental students and $29.6 \%$ of dentists in Greece [6]. Other studies have concluded that this prevalence among dentists was $77.4 \%$ in Italy [7]. In Senegal, this prevalence is not yet known and attitudes and practices in relation to hepatitis B are not yet assessed. The objective of this work is to assess the attitudes and practices of dentists in relation to hepatitis B.

\section{Method}

\subsection{Framework and Type of Study}

The study was conducted nationwide and concerned surgeons officially in service in a dental office in the country.

The investigation was done in collaboration with the College of Dentists and the Ministry of Health of Senegal (Division of Oral health). Senegal has 338 dental surgeons distributed in 260 dental structures recognized by the college and the Ministry of Health. In addition, there are cabinets installed in military establishments and other companies.

The only region in Dakar has more than 152 dental offices. The study was descriptive and transversal and focused on the Senegalese dentists. 


\subsection{Selection Criteria}

To be retained in the study, participants had to meet the following criteria: they were they hold a doctoral degree in dental surgery, they had to be practicing or exercising dental surgery at the time of the investigation, they had to be registered for the College of Dentists (except for the military), and they had to agree to participate in the study.

\subsection{Sample Size and Sampling}

The determination of sample size was calculated using the Schwartz formula [8]:

$$
n=(£ \alpha)^{2} p q / I^{2}
$$

which can be used in cross-sectional studies where $\mathcal{E}=$ reduced deviation $=1.96$; $\alpha=$ risk of error $=0.05 ; p=$ Proportion of dentists with no knowledge of hepatitis B. Failing to find a knowledge study, we estimated the prevalence to be $10 \% ; q$ $=$ The add-in $=90 \% ; I=$ accuracy $=5 \%$. These parameters resulted in size of 138 individuals. To guard against lost or damaged cards and improve the strength of our sample, we increased the size to 171 .

A systematic and several-degree stratified probabilistic sampling according to Dakar and the other regions as well as by public, private and parapublic cabinets was carried out.

The first was to draw, seven primary units constituted by the regions for essentially material reasons. At the outset the capital city Dakar was the focus due to the large concentration of firms (almost two thirds of the firms in the country). The other six regions were randomly selected by lottery on a set of 13 regions. The regions concerned were of Thiès, Ziguinchor, Diourbel, Saint-Louis, Kaolack and Fatick.

Second, secondary units consisting of 33 public offices, 5 para-publics and 109 outside the Dakar region were also drawn to the lot. For the other regions, the survey enlisted all functional cabinets at the time of the investigation.

Finally, after drawing up lists of dental surgeons from both the Dakar region and other regions, statistical units (dentists) were selected according to a systematic random sampling with a step equal to 2 surveys.

The rule of proportionality was respected with regard to the distribution of dental surgeons according to whether they are public, parapublic or private in Dakar and other selected regions. In the end, 75 private dentists and 35 public and/or parapublic surgeons from the Dakar region, and 45 of the public and/or the parapublic and 16 of the private of the other regions were investigated.

\subsection{Data Collection and Variables Studied}

The questionnaires were directly administered to the dental surgeons selected for the survey. Previously, they had been provided with explanations of the objectives and importance of the public health survey. The survey was conducted from April to June 2014. 
The survey form was pre-tested on ten students preparing their dental surgery thesis. This allowed us to observe the responses of the respondents to the survey, and to obtain estimates of the time devoted to the different sections. The difficulties and ambiguities encountered were corrected for the purpose of preparing the final investigation.

The information to be collected concerned the variables related to the attitudes and practices of dental surgeons in relation to hepatitis B. Attitudes and practices refer to the behaviour of the dentist to prevent viral infection in the dental environment (vaccination, protective equipment, sterilization processes etc...).

\subsection{Ethical Considerations}

The information contained in the survey did not identify the dentist who chose to agree to answer the questions. The answers were handled in complete confidentiality.

\subsection{Data Analysis}

The EPI info 3.4.3 software allowed us to enter and process the data. The results were expressed in terms of numbers and percentages with their confidence intervals for the qualitative and average variables followed by their standard deviations for the quantitative variables.

\section{Results}

See Table 1 and Table 2.

\section{Discussion}

This study assessed the attitudes and practices of dentists in dental surgeries and in the face of hepatitis B risk. The results may be underestimated because of the potential existence of the bias of desirability that the respondents give the best answer that does not necessarily correspond to their actual practices. Nevertheless, the evaluation showed faulty practices in relation to their hygienic practices, protective devices, their vaccination status, and their conduct followed before a case of accident of exposure to blood.

\subsection{Behaviour of Dental Surgeons at the Dentist's Office}

Gloves should be worn as soon as there is a risk of contact with blood, or any other human fluid, as well as with the mucous membranes or the injured skin of the patient.

Gloves are therefore indispensable for the care at risk of stinging, manipulation of tubes, fingerprints or contaminated material. Similarly, when the caregiver's hands have lesions, gloves should be worn during care.

Almost $95 \%$ of dentists reported wearing gloves on a regular basis before any dental act (Table 1). The Nagao et al. study [9] in 2008 in Japan, covering oral 
Table 1. Attitudes or behaviours of dentists at the dental office.

\begin{tabular}{|c|c|c|c|}
\hline Variables & Modalities & Number & $\%[\mathrm{CI}]$ \\
\hline \multirow{3}{*}{$\begin{array}{l}\text { Do you use gloves } \\
\text { for any dental act? }\end{array}$} & Never & 0 & 0 \\
\hline & Often & 9 & $5.3[2.4-9.8]$ \\
\hline & Regularly & 162 & $94.7[90.2$ - 97.6$]$ \\
\hline \multirow{3}{*}{ Are you wearing a mask? } & Never & 2 & $1.2[0.1-4.2]$ \\
\hline & Often & 21 & $12.3[7.8-18.2]$ \\
\hline & Regularly & 148 & $86.5[80.5-91.3]$ \\
\hline \multirow{3}{*}{$\begin{array}{l}\text { Do you wear glasses when } \\
\text { there is risk of splashing? }\end{array}$} & Never & 20 & $11.7[7.3-17.5]$ \\
\hline & Often & 41 & $24.0[17.8-31.1]$ \\
\hline & Regularly & 110 & $64.3[56.7-71.5]$ \\
\hline \multirow{3}{*}{$\begin{array}{l}\text { Wash your hands before } \\
\text { and after each patient? }\end{array}$} & Never & 5 & $2.9[1-6.7]$ \\
\hline & Often & 88 & $51.5[43.7-59.2]$ \\
\hline & Regularly & 78 & $45.6[38-53.4]$ \\
\hline \multirow{3}{*}{$\begin{array}{l}\text { Do you change your blouse } \\
\text { or smock at least once a day? }\end{array}$} & Never & 57 & $33.3[26.3-40.9]$ \\
\hline & Often & 86 & $50.3[42.6-58]$ \\
\hline & Regularly & 28 & $16.4[11.2-22.8]$ \\
\hline \multirow{3}{*}{$\begin{array}{l}\text { Do you rinse and disinfect } \\
\text { any prosthesis footprint? }\end{array}$} & Never & 4 & $2.3[0.6-5.9]$ \\
\hline & Often & 50 & $29.2[22.5$ - 36.7] \\
\hline & Regularly & 117 & $68.5[60.9-75.3]$ \\
\hline \multirow{3}{*}{$\begin{array}{l}\text { Do you throw the needles } \\
\text { after use into a specific box? }\end{array}$} & Never & 16 & $9.4[5.5-14.8]$ \\
\hline & Often & 18 & $10.5[6.4-16.2]$ \\
\hline & Regularly & 137 & $80.1[73.2$ - 85.7] \\
\hline \multirow{3}{*}{$\begin{array}{l}\text { Do you disinfect the work } \\
\text { surfaces after each patient? }\end{array}$} & Never & 0 & 0 \\
\hline & Often & 40 & $23.4[17.3-30.5]$ \\
\hline & Regularly & 131 & $76.6[69.5-82.7]$ \\
\hline \multirow{3}{*}{$\begin{array}{l}\text { Do you disinfect the suction } \\
\text { tube after each patient? }\end{array}$} & Never & 22 & $12.9[8.2-18.8]$ \\
\hline & Often & 29 & $17.0[11.7-23.4]$ \\
\hline & Regularly & 120 & $70.1[62.7-76.9]$ \\
\hline \multirow{3}{*}{$\begin{array}{l}\text { Do you disinfect after each } \\
\text { patient the lamp cuffs? }\end{array}$} & Never & 12 & $7.0[3.7-11.9]$ \\
\hline & Often & 94 & $55.0[47.2-62.6]$ \\
\hline & Regularly & 65 & $38.0[30.7-45.7]$ \\
\hline \multirow{3}{*}{$\begin{array}{l}\text { Do you disinfect after each } \\
\text { patient the cuspidor? }\end{array}$} & Never & 1 & $0.6[0-3.2]$ \\
\hline & Often & 26 & $15.2[10.2-21.5]$ \\
\hline & Regularly & 144 & $84.2[77.9-89.3]$ \\
\hline \multirow{3}{*}{$\begin{array}{l}\text { Do you disinfect the X-ray } \\
\text { machine after each patient? }\end{array}$} & Never & 44 & $25.7[19.4-33]$ \\
\hline & Often & 84 & $49.1[41.4-56.9]$ \\
\hline & Regularly & 43 & $25.2[18.8-32.3]$ \\
\hline \multirow{3}{*}{$\begin{array}{l}\text { Do you rinse and sterilize } \\
\text { by heat the instruments? }\end{array}$} & Never & 0 & 0 \\
\hline & Often & 12 & $7.0[3.7-11.9]$ \\
\hline & Regularly & 159 & $93.0[88.1-96.3]$ \\
\hline
\end{tabular}


care professionals, highlighted a proportion of $82.08 \%$ of professionals wearing gloves during care. This difference could be explained by the study population which was not only made up of dentists but also of hygienists and dental assistants. This would put the good behaviours that dentists may have in isolation.

Gloves should always be changed between patients or two activities. However, the wearing of gloves does not exempt from hand washing. More than half of our sample washed their hands before and after each patient (Table 1).

A blouse, mask and goggles must be worn in case of a risk of spraying or aerosolizing blood or other human fluids. In our sample, the mask wearing was regular (86.5\%) and goggles were worn when there was a risk of splashing of more than 64\%. The Barlean study [10] among Romanian dentists reported a percentage of $86.2 \%$ of dentists reporting wearing full equipment (gloves, masks, eyeglasses and coats) during care.

In the dental office, the precautions to be taken are simple. Hygiene rules are to dispose of disposable products (needles in a specific box) and disinfection, flushing of soiled surfaces and systematic sterilization of instruments. In our study, more than $23 \%$ disinfected work surfaces only irregularly; the same was the case with the fingerprints, the X-ray machine, the suction tubes with $29 \%$, $25.7 \%$ and $12.9 \%$ respectively. The sterilization of the instruments by heat was regularly done in $93 \%$ of the cases (Table 1). In the Al-Omari study [11], it emerged that all dental practitioners stated that they changed the suction tubes between patients, $63 \%$ used autoclave for sterilization, and only $18 \%$ disinfected prints before sending them to dental labs. For waste, $31.8 \%$ had special containers for the disposal of needles and other sharp objects.

\subsection{Vaccination Status of Dental Surgeons}

The hepatitis B vaccine does not cure chronic carriers, but it is effective from $90 \%$ to $95 \%$ to prevent the onset of this condition. The anti-HBV vaccine is also the first vaccine against a sexually transmitted infection and can be considered the first cancer vaccine.

More than a fifth of the dentists interviewed (21.6\%) were not vaccinated (Table 2). The study of Azodo in 2012 [12] revealed a higher percentage (31\%) of dentists who were not vaccinated against HBV in the city of Benin in Nigeria, even though the latter evoked lack of opportunities and fear of side effects of the vaccine.

\subsection{Frequency of Accidents of Exposure to Blood (BEA)}

An accident exhibiting blood (BEA) is defined as any accidental contact with blood or a biological liquid contaminated with blood, following a cutaneous break-in (stick, cut, scratch...) or a projection on a mucous membrane (conjunctiva, mouth...) or on an injured skin (dermatosis, wound...). Surgeons remain the most exposed category of personnel in terms of BEA frequency.

These BEA were relatively common in dental surgeons in our sample because 
Table 2. Vaccination status. Blood exposure accidents (BEA). And behaviour of dentists in the face of risk of contamination.

\begin{tabular}{|c|c|c|c|}
\hline Variables & Modalities & Number & $\%[\mathrm{CI}]$ \\
\hline \multicolumn{4}{|c|}{ Statut vaccinal } \\
\hline \multirow{2}{*}{$\begin{array}{l}\text { Are you vaccinated } \\
\text { against hepatitis } B \text { ? }\end{array}$} & Yes & 134 & $78.4[71.4-84.3]$ \\
\hline & No & 37 & $21.6[15.7-28.6]$ \\
\hline \multicolumn{4}{|c|}{ Blood exposure accidents } \\
\hline \multirow{4}{*}{$\begin{array}{l}\text { Frequency of needle sticking } \\
\text { during the last } 3 \text { months }\end{array}$} & 0 time & 138 & $80.7[74-86.3]$ \\
\hline & 1 time & 22 & $12.9[8.2-18.8]$ \\
\hline & 2 times & 8 & $4.7[2-9]$ \\
\hline & 3 times and more & 3 & $1.7[0.1-7.4]$ \\
\hline \multirow{4}{*}{$\begin{array}{l}\text { Frequency of splashing } \\
\text { in the eyes during } \\
\text { the last } 3 \text { months }\end{array}$} & 0 time & 75 & $43.9[36.3-51.6]$ \\
\hline & 1 time & 17 & $9.9[5.9-15.4]$ \\
\hline & 2 times & 27 & $15.8[10.7-21.1]$ \\
\hline & 3 times and more & 52 & $30.4[15.8-57.4]$ \\
\hline \multirow{4}{*}{$\begin{array}{l}\text { Frequency of injuries caused } \\
\text { by sharp instruments } \\
\text { during the last } 3 \text { months }\end{array}$} & 0 time & 153 & $89.5[83.9-93.6]$ \\
\hline & 1 time & 10 & $5.8[2.8-10.5]$ \\
\hline & 2 times & 4 & $2.3[0.6-5.9]$ \\
\hline & 3 times and more & 4 & $2.4[0-3.2]$ \\
\hline \multirow{6}{*}{$\begin{array}{l}\text { Your attitude in case of } \\
\text { bites or injuries }\end{array}$} & \multicolumn{3}{|l|}{ Action to be taken } \\
\hline & Disinfection & 89 & $52.1[44.9-60.4]$ \\
\hline & Rinsing & 3 & $1.7[0.4-5.1]$ \\
\hline & Disinfection and rinsing & 22 & $12.9[8.3-19]$ \\
\hline & Other & 50 & $29.2[22.8-37.1]$ \\
\hline & Nothing & 7 & $4.1[1-6.8]$ \\
\hline \multirow{5}{*}{$\begin{array}{l}\text { Your attitude in case of } \\
\text { splashing in the eyes }\end{array}$} & Disinfection & 11 & $6.4[2.5-9.9]$ \\
\hline & Rinsing & 114 & $66.7[59.8-74.5]$ \\
\hline & Disinfection and rinsing & 19 & $11.1[6.9-17]$ \\
\hline & Other & 24 & $14[9.3-20.4]$ \\
\hline & Nothing & 3 & $1.8[0.4-5.1]$ \\
\hline
\end{tabular}

nearly $13 \%$ had at least once needle sticks, $10 \%$ of the splashes and $6 \%$ of the injuries caused by sharp instruments (Table 2). Azodo et al. en 2010 reported a frequency of $41 \%$ of blood exposure accidents occurring in a 12 -month period on a population of auxiliary dentists in Nigeria [13]. The high proportion noted in this last study is probably due to their status as auxiliary dentists.

\subsection{Measures to Be Followed in the Event of BEA}

In spite of the context at risk, most often characterized by the ignorance of patients of their general state, the lack of protective devices and the frequency of 
accidents of exposure to blood during oral care, the majority of dental surgeons (52.1\%) stated that they had to conduct the disinfecting of the site in case of sticks or wounds. However, in the case of splashes, $2 / 3$ of the sample selected rinsing only (Table 2).

In Iran, the work of Shaghaghian [14] reported that $43 \%$ of dentists believed that an immediate flushing of the exposed surface following a stick, injury, or splash had no effect on the prevention of hepatitis B. This result does not follow the trend we have found, and can be subject to many interpretations.

\section{Conclusion}

The attitudes and practices of the Senegalese dentists in the face of hepatitis $B$ need to be improved for both patients and the practitioners themselves. It urges the organization of awareness-raising sessions on the need for vaccination and to build capacity on the observance of hygiene measures, protective equipment and devices, and the proper procedures to be taken in the event of accidents involving exposure to blood.

\section{References}

[1] World Health Organization (2014) Hepatitis B. Checklist 2014; N²04. http://www.who.int/mediacentre/factsheets/fs204/fr/

[2] Alter, M.J., Hadler, S.C., Margolis, B.S., Bloom, B.S., Hillman, A.L., Fendrick, A.M. (1990) The Changing Epidemiology of Hepatitis B in the United-States. Need for Alternative Vaccination Strategies. Jama, 263, 1218-1222. https://doi.org/10.1001/jama.1990.03440090052025

[3] Redd, J.T., Baumbach, J., Kohn, W., Nianan, O., Khristova, M. and Williams, I. (2007) Patient-to-Patient Transmission of Hepatitis B Virus Associated with Oral Sugery. The Journal of Infectious Diseases, 195, 1311-1314. https://doi.org/10.1086/513435

[4] National Programme to Combat Hepatitis. World Day to Fight Hepatitis. http://worldhepatitisday.org/showyourface

[5] Houdart, P. (1989) Hepatitis B, Two Out of Three Doctors in Danger. Impact Med, 3, 24-26.

[6] Panis, B., Roumeliotou-Karayannis, A., Evangelou, G., Richardson, S.C. and Mitsis, F. (1986) Hepatitis B Virus in Dentists and Dental Students in Greece. Oral Surgery, Oral Medicine, Oral Pathology, Oral Radiology, 61, 343-345.

[7] Bramilla, E., Cagetti, M.G., Fadini, L., Tarsitani, G. and Strohmenger, L. (2005) Epidemiological Investigation of Medical and Non-Medical Personnel in a Public Dental Clinic. Annali Di Igiene, 17, 155-162.

[8] Ancelle, T. (2003) Statistics of Epidemiology. Editions Maloine, Paris, 300 p.

[9] Nagao, Y., Matsuoka, H., Kawaguchi, T., Ide, T. and Sata, M. (2008) HBV and HCV Infection in Japanese Dental Care Workers. International Journal of Molecular Medicine, 21, 791-799. https://doi.org/10.3892/ijmm.21.6.791

[10] Bârlean, L., Săveanu, I. and Balcoş, C. (2014) Dental Patient's Attitudes towards Infection Control. Revista Medico-Chirurgicala a Societatii De Medici Si Naturalisti Din Iasi, 118, 524-527. 
[11] Al-Omari, M.A. and Al-Dwairi, Z.N. (2005) Compliance with Infection Control Programs in Private Dental Clinics in Jordan. Journal of Dental Education, 69, 693-698.

[12] Azodo, C., Ehizele, A., Uche, I. and Erhabor, P. (2012) Hepatitis-B Vaccination Status among Dental Surgeons in Benin City, Nigeria. Annals of Medical and Health Sciences Research, 2, 24-28.

[13] Azodo, C., Ehigiator, O. and Ojo, M.A. (2010) Occupational Risks and Hepatitis B Vaccination Status of Dental Auxiliaries in Nigeria. Medical Principles and Practice, 19, 364-366. https://doi.org/10.1159/000316374

[14] Shaghaghian, S., Pardis, S. and Mansoori, Z. (2014) Knowledge, Attitude and Practice of Dentists towards Prophylaxis after Exposure to Blood and Body Fluids. The International Journal of Occupational and Environmental Medicine, 5, 146-154. 